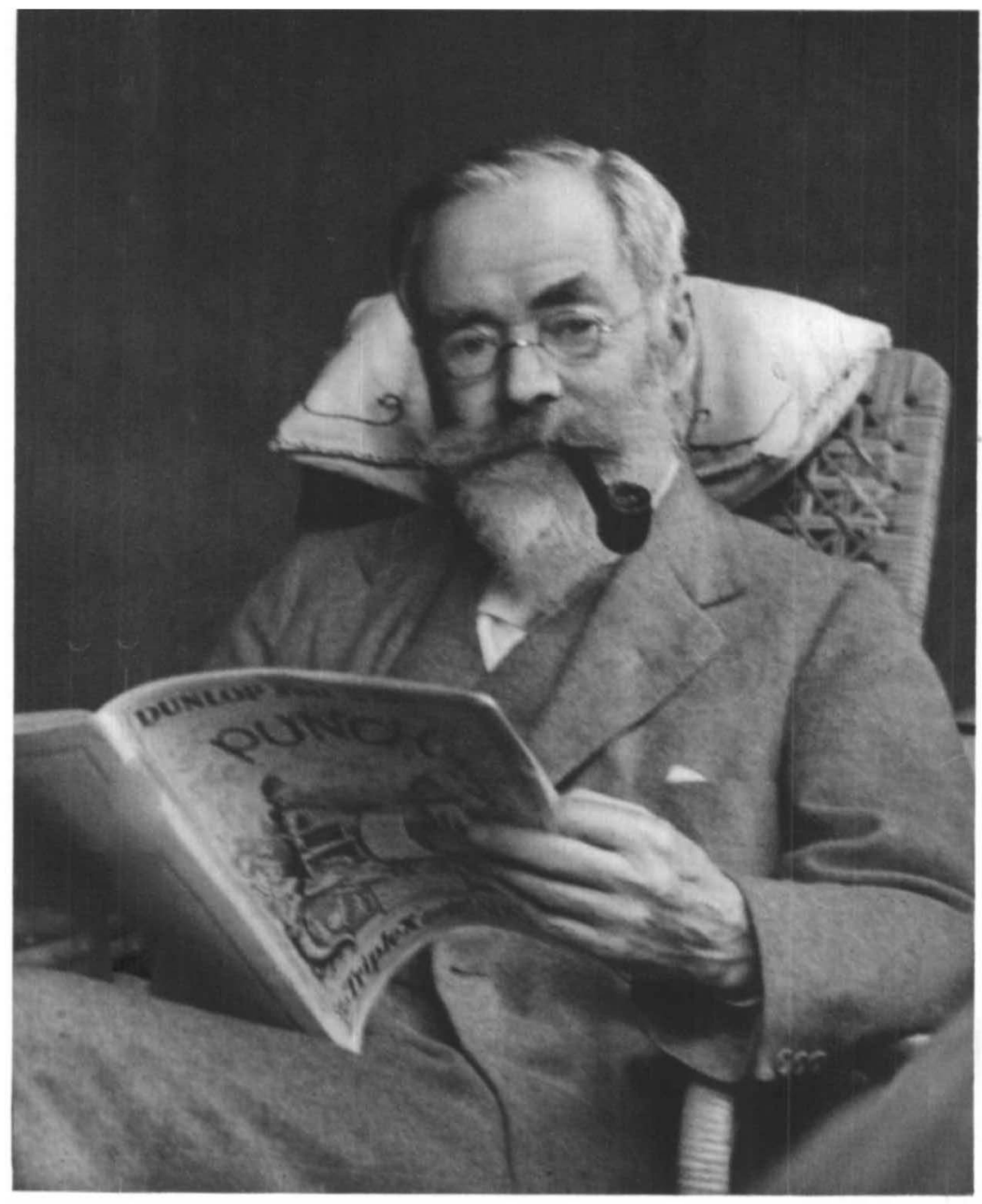

Gerphidter. 


\section{GEORGE PARKER BIDDER}

\section{I863-I953}

The death of George Parker Bidder in his 9Ist year on 3I December 1953 has removed our last personal link with the days of the early development of the Marine Biological Association and its struggle for existence between the end of last century and a few years before the First World War. After the death of E. J. Allen in 1942 the only other survivor who had played a major part in the story besides Bidder was Walter Garstang, who died in 1949. Apart from those like Allen and Garstang, who were directly responsible for carrying out the work for which the Association was founded, no one contributed more vitally to its final success than Bidder, whose shrewd counsel and wise benefactions were undoubted factors in the survival of the Plymouth laboratory. In these days of recognition by the Government of the needs of science it is not easy for us to appreciate what the difficulties must have been for those who had to prove to an unresponsive audience that marine biological research was worth while. Those men were remarkable in their generation, and one of the most remarkable of them was G. P. Bidder.

George Parker Bidder was born in London on 21 May 1863. His life fulfilled the expectations aroused by the endowment of unusual gifts and characteristics passed to him through his parents. His father, George Parker Bidder, Q.C., was the son of George Parker Bidder, C.E., the 'calculating boy'. His mother was Anna McClean; her father was the engineer J. R. McClean, F.R.S., and her brother was Frank McClean, F.R.S. From his father's side George Parker Bidder the third inherited, among many gifts, especially his power of calculation and his unusual memory; from his mother's side came in part, at least, that remarkable vision and judgement which led him to do so many things at the right time, and his ability to handle people with ease and harmony.

His grandfather, George Parker Bidder the first, was born at Moretonhampstead on the north-eastern borders of Dartmoor in 1806 . The son of a stone-mason, he had an amazing natural ability for calculation, and was taken round the countryside for profit as the 'calculating boy'. Thanks to the intervention of certain gentlemen he was enabled to have University training and eventually became a leading railway engineer, collaborating with the Stephensons. In later years he owned an estate at Mitcham, south of London, known as Ravensbury Manor, where his grandson often stayed as a child. Later, when

The frontispiece is from a photograph taken in 1934 by Ramsey and Muspratt, of Cambridge, who have kindly given permission for its reproduction. 
owing to ill-health he moved to Ravensbury, Dartmouth in Devon, his son occupied Ravensbury Manor, Mitcham, and it became the grandson's home.

George Parker Bidder, the third, was educated at King's Preparatory School, Brighton, and at Harrow, where he was in the sixth under Dr Butler. While at Harrow he won the Prize Poem in I881. On leaving Harrow Bidder spent one year at University College, London, on the advice of F. M. Balfour, attending the lectures of Ray Lankester, virtually the founder of the Marine Biological Association, its first Honorary Secretary, and its President from I 890 to I929. After completion of this year he went as an Exhibitioner in Mathematics and Science to Trinity College, Cambridge, where he took the Natural Science Tripos in 1884 and 1886 . On his arrival in Cambridge, Balfour having recently died, the lecturers in zoology were W. F. R. Weldon and S. F. Harmer. On one occasion these two took young Bidder shorecollecting in Guernsey and it is possible that this strengthened an interest in marine biological research apparently first aroused by reading Jules Verne's Twenty Thousand Leagues Under the Sea; although as a boy he had not been without experience of the sea, having cruised from Dartmouth in his grandfather's yacht Mayfly. He was later to own his own yachts the Chanceit and Myrtle in which he used to sail at Plymouth.

On the completion of his degree Bidder went to the Zoological Station at Naples where he held the Cambridge University table in 1887 , '88 and ' 89 , and was the guest of Anton Dohrn in 1890, '9I and '93. It was during these years that he did much of his experimental work on sponges which was not to see publication until some thirty years had passed.

While in Naples Bidder, whose appreciation of visual beauty was always acute, became much interested in sculpture and archaeology; this interest led later to a small publication entitled Arcus, giving convincing arguments that this word was used for bow-drills. During this period, also, he purchased a hotel in Naples which he called 'Parkers' and ran successfully for many years, an act which has now become legendary.

Bidder also became extremely proficient in long-distance and underwater swimming; he would no doubt have been fascinated by the possibilities for underwater research opened up by modern free-diving appliances.

Bidder made his first visit to the Plymouth laboratory in 1890 , but he did not work there until I893, being recorded in the Reports of Council for that and the succeeding two years as working on 'sponges'. In I893 E. J. Bles was Director and E. J. Allen was a visiting research worker. It was then that Allen and Bidder met for the first time, and it was no doubt an appreciation of Allen's greatness, coupled with the deep friendship that developed between them, that moved Bidder to devote so much loving thought to the affairs of the Association. Allen became Director on I2 January 1894. One of his first publications after taking up his duties was a report on the sponge fishery of Florida and the artificial culture of sponges, prepared at the request of the 
Colonial Office, with a view to the introduction of sponge culture in the Bahamas. Bidder was by then an authority on sponges, and it was natural that Allen should have called on him for assistance. Allen's report was followed in the Fournal by a note by Bidder on projects for the improvement of sponge fisheries. Perusal of this paper shows how far ahead of his time Bidder was in his functional outlook. A reminder of his experience as an underwater swimmer also is to be found in his suggestion that naked divers should be encouraged to try the use of water spectacles: "while every student knows that the imperfection of the submerged human eye can be corrected by convex lenses, there is a wide gulf of ignorance separating the student from the pearldiver of the Indian Ocean'.

From I893 to I896 Bidder was a regular visitor at Plymouth, but in 1896 his father died and a great amount of business fell on his shoulders. Amongst other things he inherited interests in a dock, a dry dock, a colliery, a Danish gas company, a derelict Cornish lead mine, and a farm at Mitcham. He is not recorded among the list of visiting research workers at Plymouth again until the year 1899 when he married Marion Greenwood, a physiologist of some distinction, and they came to live in Plymouth. The Bidders remained in Plymouth until 1902 after the birth of their elder daughter Caroline, now Mrs Barclay Russell and the mother of two girls and a boy of whom their grandfather was very proud. They then moved to Cambridge and shortly into Cavendish Corner, which was to remain the home until he died. In 1903 was born their younger daughter Anna, who is now a Founder of the Association.

During the period since his father's death, in addition to his zoological and other cultural activities, Bidder had been attending monthly meetings of the Board of Directors of Cannock Chase Colliery (he was managing director from 1897 to 1908, and chairman from 1915 to 1919), making occasional visits to Denmark, and going annually to his hotel in Naples. In 1903 he began to complain of a tiredness from which he had been suffering for many years and by 1905 he was definitely shown to have tuberculosis. This illness, during which he was forbidden to use a microscope, struck at a time of life when he should have been in his prime. He made winter visits to Davos and to Assouan, and indeed was at one time given only a few months to live. Yet after ro or I2 years of this semi-invalidism and care he made a complete recovery.

During those years, however, Bidder was in fact anything but inactive. He had the time to do an immense amount of wide reading, thus gaining that great breadth of knowledge from which he so evidently drew in his conversation and publications. For several years, from 1909 to 1913 , he went with his family each autumn to Mundesley on the Norfolk Coast. Here he became very much interested in the local geology and coastal erosion. At home also he was known to spend much time in his bathroom experimenting with his bottomtrailers designed for the study of currents in the North Sea. The knowledge so derived led to a demand by the Admiralty for his services during the 1914-I8 
war when he was attached to H.M.S. Vernon for research. By 1909 he had already adopted those habits of unusual hours for which he became so well known and which persisted until the end of his life; in fact he was often said to be like the Snark in that 'he would frequently breakfast with afternoon tea and dine on the following day'.

It was during the earlier period of his illness that Bidder was also especially active in the affairs of the Marine Biological Association. By 1909 he had played a part which must have been vital to the future of all marine biological and fisheries research in this country. In 1902, under the auspices of the International Council for the Exploration of the Sea, the southern North Sea and English Channel were allotted to England for investigation. There being no government department in England concerned with Fishery Research, H.M. Treasury requested that the Association should act as agents to the Government for the equipment and working of a vessel to do research in this southern British area, the Scottish Fishery Board having consented to act in a similar capacity for the northern area. The Hon .Treasurer (J. A. Travers), the Hon. Secretary (E. J. Allen) and G. P. Bidder, together with W. Garstang, were appointed by the Council a committee to inquire as to the best means of providing a suitable vessel for carrying out the investigations and to draw up a scheme of organization for the work. For the investigations in the English Channel it was decided to use the Oithona, the acquisition of which vessel by the Association had been made possible by Bidder in 1901. As regards the North Sea investigations the Government were unable to consider the purchase of a ship, and it was necessary to charter. In August 1902 the Secretary reported to the Council that ' $\mathrm{Mr}$ Bidder had made an offer to purchase a steam trawler which he would let to the Association upon favourable terms for use in the International Investigations'. The vessel he purchased was a II5 ft. steam trawler, the Khedive, which was renamed Huxley, in honour of the first President of the Association.

In the minutes of the Association is to be found the following: 'Council wishes to place on record its sense of the value of $\mathrm{Mr}$ Bidder's generous assistance in obtaining a vessel for the purposes of the N. Sea exploration.' For this North Sea work the Association rented a house in Lowestoft, and it is to be noted that in each of the years 1903 to 1906 Bidder was appointed to the Committee to visit and report on the work of the Lowestoft laboratory.

In 1905 the Council of the Association were asked to consider whether the work on which they had hitherto been engaged could not be carried out on a reduced scale in future, so as to admit of a substantial sum being allocated to the Board of Agriculture and Fisheries for the collection of statistics. On 28 June 1905 the 'Treasury sanctioned a grant of $£ 5000$ a year for two years' further work on the international investigations, saying 'This sum is less by £500 than the grant hitherto allocated to the Association from votes of Parliament; but my Lords understand that Mr G. P. Bidder has generously 
offered to return to the Association a sum of $£ 500$ a year for two years in respect of the money paid to him for the hire of the Steam Trawler Huxley, so that the Association will be enabled through his liberality to carry on its scientific work on the same scale as in the past three years.' The Council considered 'that this offer has been the means of a satisfactory arrangement being made by the Treasury for the continuation of the English scientific work'.

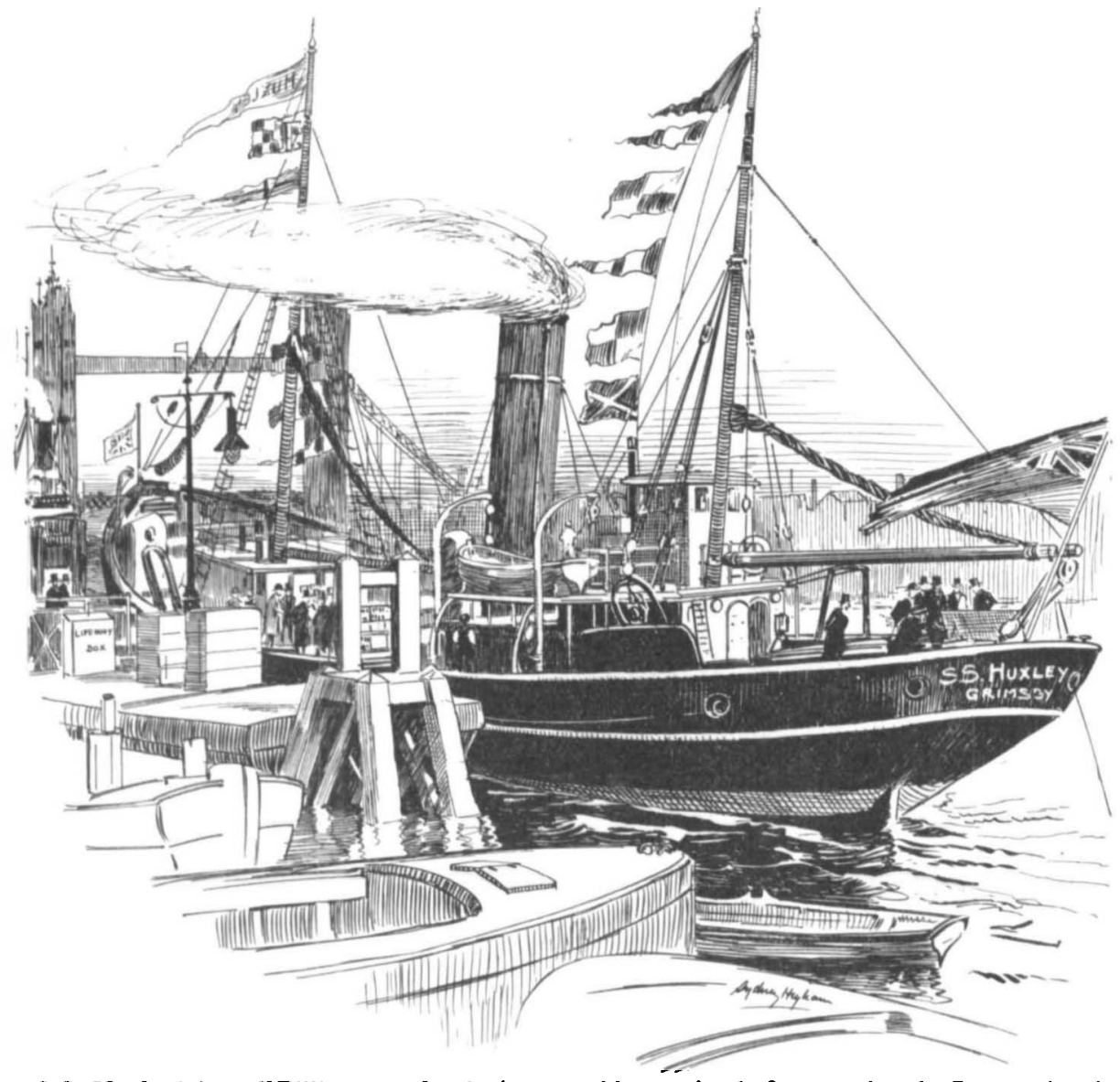

S.S. Huxley lying off Billingsgate for the inaugural inspection before starting the International Investigations in the North Sea. (From a drawing reproduced in the Daily Graphic of 3 December 1902.)

In 1907 Bidder sold the Huxley to the Association on easy yearly terms of payment on condition that, when the Association finally sold the vessel, any profits on the original cost might be kept by him to found a trust for research. In 1909 the Huxley was sold with a profit of $£ 750$ with which Bidder founded the Ray Lankester Fund to enable selected investigators to work at the Plymouth laboratory. 
The Huxley did an immense amount of pioneer research, and I have outlined its history at some length because there can be no doubt that this, made possible by Bidder, must have weighed heavily in the Association's favour in its most critical year, 1909. In that year it was proposed that the Board of Agriculture and Fisheries should take over responsibility for English marine research; and eventually the whole of the Association's scientific staff, except for Allen, became government officials. A deputation led by (Sir) Arthur Shipley called on Lloyd George, as Chancellor of the Exchequer, to state the case for continuation of the work under the Association. Although the Government won the day on the point at issue, the Marine Biological Association and its Plymouth laboratory survived, having proved the value of fundamental research as providing necessary background knowledge for fishery investigations.

A vivid account of the early days of the Association and of some financial affairs is given by Bidder himself in his obituary of E. J. Allen in this fournal (Vol. 25, p. 67I); it is characteristic that there is little mention of his own hand in these affairs.

In the submission of George Parker Bidder's name as the first Honorary Member of the Association at the Annual General Meeting on 4th July 1945 the newly elected President Prof. (Sir) James Gray said: 'We recall with particular gratitude the decisive support which Dr Bidder has given to this Association since he first became a member. During this period the Plymouth laboratory has moved far beyond the objectives which must originally have seemed possible; as each milestone has been reached it has been Dr Bidder's wise foresight, courageous faith and financial aid which made it possible to maintain the advance.' Here followed allusion to the vessels Oithona and Huxley of which I have already told. Then the President continued: 'Just before the outbreak of the First World War, it became obvious that the buildings at Plymouth were becoming inadequate-particularly for the newer aspects of biology then beginning to attract attention in this country and abroad. In the doldrums after the war Dr Bidder convinced the Council that bold and effective action should be taken, and, once again, made these plans financially practicable. So it has been at each subsequent stage in our history; Dr Bidder's foresight, courage and determination has seen us through. When we survey our present-day activities and gratefully acknowledge the extent to which we owe these to Government support, we must not forget the debt which we owe to Dr Bidder. The early years of this century were a very critical period in our life history and had it not been for his efforts, and his unflinching determination, no amount of Government aid would afterwards have enabled us to avoid disaster. The financial contributions which $\mathrm{Dr}$ Bidder has made from time to time amount to a munificent sum, but it has been the time at which they were given and the encouragement which they inspired which have been decisive in the development of the Plymouth Laboratory. Bis dat qui cito dat.' 
It was this latter characteristic of right timing which enabled Bidder to play so decisive a part, not only in the affairs of the Marine Biological Association, but in the general development of zoology in this country. Such occasions were, his purchase of the Quarterly fournal of Microscopical Science; his formation of the Company of Biologists and resulting saving of the Fournal of Experimental Biology; and his quick action at the end of the Second World War in persuading the Royal Society to come to the assistance of the Stazione Zoologica at Naples.

Bidder's love for Naples was, perhaps, second only to that for the Marine Biological Association. Reinhardt Dohrn says in a letter to me:

'Among the younger generation of British friends-young as compared to the generation of T. H. Huxley, Francis Balfour, and Ray Lankester-it was G. P. Bidder who had most probably the closest contact and personal friendship with Anton and Marie Dohrn. He must have been frequently at our house during the eighties and the nineties because, young as I was then, I have a distinct recollection of him and his vivid conversation and his characteristic laugh. My parents mentioned him often, him and also the famous, almost classic story, of how he came to take over the bankrupt hotel on the Corso Vittorio Emanuele, which later became such a success as Parker's Hotel.'

Dohrn speaks of Bidder's help to the Stazione between the wars and says:

'It was Bidder's strong wish to keep alive the personal contact between the British biologists and the Zoological Station, and equally alive was his tendency to act as a catalyser of these contacts. Of this, I too have also had proof again and again. But especially so after the last war when a critical situation threatened the Zoological Station and when it seemed doubtful whether the tradition of the Stazione could be continued. Bidder then intervened decisively in more than one case. I am glad to have an opportunity to state this fact here: on I4 October, 1943, scarcely two weeks after the allies had occupied Naples, Bidder-as Chairman of the Marine Biological Association -wrote a letter to the Editor of The Times in which he expressed his joy about the news that the Zoological Station had been spared. Many of his fellow countrymen would share his joy because many of them had worked at Naples. And of special value to us here was the fact that he gave vent to his joy "that the Director (friend of us all) was still there in charge in August" (and that this "gave grounds for hope that we may yet see in the Stazione again men of many tongues and more nations working side by side in the fraternity of a common endeavour to understand the living world that surrounds us") which meant that also in the future the Station would go on in the old tradition.

This letter written by Bidder has been of great significance for the fate of the Zoological Station. There was, at that time, a kind of "Reader's Digest", edited in Italian by the Military Authorities, called il Mese (the Month). In no. 3, December 1943, Bidder's letter to The Times was published in Italian. What that meant for the position of the Zoological Station then, and to myself 
and my collaborators, need not be emphasized to you. But more was to come: two months later the Allied Military Government informed us that the Royal Society had decided on an emergency grant of $£$ rooo.'

Bidder, who was awarded the Sc.D. of Cambridge in 1916, was a prominent figure in biological circles. He was on the Council of the Marine Biological Association from 1899 until his death, a Governor of the Association from 1905, and its President for the years 1939 to 1945. When he resigned from his Presidency the Council instituted the election of Honorary Members of the Association so that they might show their appreciation to Bidder by bringing forward his name as the first to be elected. His last visit to Plymouth was in 194I during the air raids when the laboratory was badly damaged. The destruction of Plymouth and the haunts he knew so well as a young man caused him great distress.

His colliery interests and knowledge of coal mines made him the obvious secretary for the British Association Committee which reported in 1904 on the probability of Ankylostoma (Miner's Worm) becoming a permanent inhabitant of British coal mines in the event of its introduction.

He was President of the Zoological Section of the British Association in 1927. During his year of office he thought that it would be valuable to have intermediate meetings of the section. The Recorder of that day, Prof. Frank Balfour-Browne, being in favour of the suggestion, Bidder and he started to arrange a meeting for January. The Council of the British Association did not, however, approve, so these two started the Association of British Zoologists, of which Bidder was the first Chairman, a position in which he excelled. He was Vice-President of the Linnean Society in 1924 and 193I, and its Zoological Secretary from I928 to I93I; and an Honorary Vice-President of the Ray Society. He was President of the Devonshire Association in 1929, and of the South Western Union of Naturalists in 1928; to both he gave Presidential addresses proving his wide knowledge and the originality of his outlook. From 1920 to 1927 Bidder gave the course on sponges for Part II students at Cambridge and it was my privilege to be one of the first to listen to these fascinating and stimulating lectures. Bidder loved microscopy, and in his practical teaching he insisted upon the right use of the microscope. It was only by making the best possible use of the instrument that fine details of the cell could be seen, for throughout his work it was the living cell and its complexity that fascinated him. He edited Vosmaer's posthumous Bibliography of Sponges which was published in 1928.

As regards his own scientific research, Bidder's two major contributions to knowledge were on the hydraulics of the sponge, and the invention of the bottom-trailer, a bottle so weighted. that it was only just heavier than sea water and would drift in bottom currents.

The work on sponges was started at Naples during the years 1887 to 1892 and continued at Plymouth from I893 to I896, but the first full report was not 
made until the British Association Meeting in Hull in 1922, when E. J. Allen was President of Section D. It was published in the Quart. $\mathcal{F}$. micr. Sci. the following year. 'For a long time I proposed to myself to make a further series of experiments to clear up doubtful points, but recognizing that I shall not now do so, I have reconsidered all the experiments this year (1922) and recalculated all results and formulae.' He did, in fact, later work for short periods at Plymouth and at Naples, on the currents of sponges, on which he read a paper at the British Association at Leicester in 1933.

It is generally recognized that Bidder was well in advance of his time when he did the research last century which led to his two papers 'The relation of the form of a sponge to its currents' and 'The perfection of sponges'. Their delayed publication until 1923 and 1937 covered the period of the general rise in this country of functional morphology and experimental biology. The papers were models of lucidity; mathematical calculations were relegated to appendices, and the results were available in simple language for all to understand. One of their characteristics was the illustration of details by comparison with graphic everyday phenomena. 'I worked with two calcareous species of sponges, having oscula at the end of tubular prolongations, which reach the size and shape of a child's thumb in the case of Leucaltis, and of a child's finger in the case of Leucandra aspera'.

While remarking that under the microscope flagella appear to move with the speed of an express train, in fact, he says 'no part of the most rapidly moving flagellum ever attains the rapidity of motion of a snail'. To illustrate that there is no co-ordination in the movement of the flagella in a sponge he says 'A collar cell flagellate surface is comparable mechanically to a seine-net with a number of fishes fixed by their gills in the meshes.'

Again 'The remarkable achievement of the perfected hydraulic organ in sponges is that from this waving of hairs $\frac{1}{100000}$ of an inch in thickness at a mean speed of 7 feet an hour, there is produced an oscular jet with an axial velocity of over half a foot a second (280 times the speed of the flagellum), which in Leucandra throws to the distance of 9 inches five gallons a day or a ton in six weeks.' This is a good example of how he stressed the comparison of time and distance in small organisms.

For those species of deep-water Hexactinellida set in a vertical plane with no evolution of pressure chambers: 'Food is brought to them, waste is taken away. For them in their eternal abyss, with its time-like stream, there is no hurry, there is no return. Such an organism becomes a mere living screen between the used half of the universe and the unused half-a moment of active metabolism between the unknown future and the exhausted past.'

The following is very typical: 'A pretty method was arrived at accidentally, when I found the coloured jet marked by dark beads or nodes, caused by my pulse shaking the pipette; the length between any two nodes, divided by threequarters of a second, gives the core-velocity of that part of the jet.' Bidder 
once told me how valuable he found a musca volitans in his eye for microscopic work: he had calibrated it for different oculars and objectives of his microscope and could use it as a quick approximate eye-piece micrometer for measurements.

His sense of humour was keenly developed, and all his discussions were liable to be punctuated at intervals by that characteristic laughter when he had suddenly noted a humorous aspect. This sense could not be withheld even from his writings. Discussing the ancient history of sponges and climates in his Presidential Address to the British Association Zoology Section at Leeds he said: '. . so that 10 or 20 million years would give them as many steps in evolution, to make a flagellate from nothing, as it has taken us to build up a flagellate into that highest of all living creatures, a member of the British Association (section D)'. Or, when writing on flagellar motion 'at higher frequencies the stroke is the shorter, as in a school-master's cane; at lower frequencies the stroke is the longer, as in a fisherman's trout-rod'.

Many of his remarks have deep significance. In an article in the British Medical fournal on Senescence he says: 'I suggest that we were not born with infinitely senescent brains and rejuvenated epithelium; rapidity of division in our skin has been evolved to keep it clean and whole; undivided brain cells have been evolved because their function is to remember.' On a visit to his house in 1945 (he was then 82) he took me across his lawn for his daily reading of the maximum and minimum thermometer. On being asked why he kept the thermometer so far from the house he said that it was so that he could daily exercise his memory, as he did not write the readings down until he had returned indoors.

Bidder wrote a number of other papers on sponges besides the two I have specially mentioned. Of these remaining papers $\operatorname{Dr} M$. Burton writes: 'Although fairly numerous, they were all short, but he contrived to include the occasional idea that was of fundamental importance, the most outstanding being his emphasis on the distinctness of the Hexactinellida from the rest of the Porifera, epitomized in his use of the phyla Nuda and Gelatinosa.'

Bidder's invention of the bottom-trailer, in the words of Dr J. N. Carruthers '... represented a powerful means of attack in the study of bottom water movements. Bidder found the important result that the main drift in all his series, when generally summarized, seemed to be in the opposite direction to the migration of the plaice at the same time of year. "So far therefore" he concluded "the experiments confirm the view of those naturalists who suppose that bottom feeders, like trout, tend to move against the current".

Moreover, Bidder expressed the opinion that his evidence favoured the supposition that the percentage of bottles in a given area recovered by the trawl did not differ largely from the percentage of plaice of $21-26 \mathrm{~cm}$ in the same area caught by the trawl in the same time. Hence the bottles serve as an instrument for assessing the intensity of trawling because they cannot migrate. 
Bidder, in a manuscript given to me, stated that his bottles were trawled up by the fishermen at the rate of $55 \%$ per annum.

$\mathrm{He}$ deduced the time of onset of the winter drift from south to north in the southern North Sea and of the draught getting into the Skagerrak with the onset of winter. This latter he found makes itself felt by degrees further and further south without drawing on the English Channel water until the end of the year.

Of course, the most significant thing was Bidder's finding that many of his bottom-trailers got cast on the English shore, whereas surface bottles would, for the most part, go across the North Sea. He deduced, regarding the bottom flow, that the isochrones (his word) of the stream-front were shaped on the shoreline; and such a formation of the bottom current at once suggested to him the creeping-in of heavy water. This is of course now well known-that river outflow induces an ingoing bottom set of salt water.'

I have been privileged to see extracts from many of the tributes sent to his family by his friends young and old. While many recalled his culture, his original and fascinating conversation, his child-like curiosity, or his ingenuity, all stressed his courteous and kindly nature. No young student was beneath his consideration, and the numbers, in all stations, whom he helped by word or deed, will never be known. Truly his left hand knew not what his right hand gave.

In conclusion, I cannot improve upon the words of the obituary notice in The Times of I January 1954: 'But perhaps he brought to the service of humanity and of science qualities rarer and more important than those which have given other men greater reputations. For the timely help and wise advice which he gave to many, both scientists and non-scientists, were guided by unusually understanding sympathy, and were completely unselfish. These qualities had as their natural symbol his unfailing and distinguished courtesy; and that also helped to give its characteristic style to that sturdy bearded figure with white tie, Inverness cape, and quite unconsciously patrician bearing, whose departure many men and women in all branches of study and in all ranks of society will now most sorely regret.'

F. S. RUSSELL 


\section{PUBLISHED WORKS BY G. P. BIDDER}

\section{Scientific}

I891. Review of 'A Monograph of the Victorian Sponges', by Arthur Dendy. Quart. F. micr. Sci., Vol. 32, pp. 625-32.

1892. Note on excretion in sponges. Proc. roy. Soc., Vol. 5I, pp. 474-84.

1895. The collar-cells of Heterocoela. Quart. F. micr. Sci., Vol. 38, pp. 9-43.

1896. Note on projects for the improvement of sponge-fisheries. F. Mar. biol. Ass. U.K., Vol. 4, pp. 195-202.

I898. The skeleton and classification of calcareous sponges. Proc. roy. Soc., Vol. 64, pp. $6 r-76$.

1902. Notes on Plymouth sponges. F. Mar. biol. Ass. U.K., Vol. 6, pp. 376-82.

1905. Account of some experiments on bottom-trailers. Rapp. Cons. Explor. Mer, Vol. 4, B, pp. I02-3.

1906. Principal results of the experiments with bottom-trailers. Rapp. Cons. Explor. Mer, Vol. 6, A, pp. xxxy-xlii.

1920. The fragrance of Calcinean sponges and the spermatozoa of Guancha and Sycon. F. Linn. Soc. (Zool.), Vol. 34, pp. 299-304.

1920. Syncrypta spongiarum, nova. F. Linn. Soc. (Zool.), Vol. 34, pp. 305-13.

1920. Notes on the physiology of sponges. F. Linn. Soc. (Zool.), Vol. 34, pp. 31 5-26.

1923. The relation of the form of a sponge to its currents. Quart. F. micr. Sci., Vol. 67, pp. 293-323.

1925. The origin of sponge-spicules. Nature, Lond., Vol. I I5, pp. 298-9.

1925. Growth and death. (Abstract.) Proc. Linn. Soc. Lond., Sess. 137, 1924-25, pp. I7-20.

1927. The ancient history of sponges and animals. Rep. Brit. Ass. (Presidential Address, Sect. D, Zool.), 1927, pp. 58-74. (Also Nature, Lond., 24 Sept. 1927.)

1928. Presidential Address. Proc. S.W. Nat. Un., 7 pp.

1928. Some sponges of the south-west coast. Proc. S.W. Nat. Un., 1927, pp. 12-20.

1929. The interpretation of the embryology of sponges. Rep. Brit. Ass., Vol. 96, p. 565 .

1929. Geotropism and antennae. Nature, Lond., Vol. 123, p. 799.

1929. The sea. (Address of the President.) Trans. Devon. Ass., Vol. 6I, pp. 57-73.

1930. On the classification of sponges. (Abstract.) Proc. Linn. Soc. Lond., Sess. I4I, I928-29, pp. 44-7.

I930. On the attitude of a Hexactinellid at the bottom of the sea, as compared with that assumed in museum jars and monographs. Proc. Linn. Soc. Lond., Sess. 142, 1929-30, pp. 69-72.

I931. The importance of cataclasms in evolution. Proc. Linn. Soc. Lond., Sess. I42, 1929-30, pp. 40-3.

1931. The biological importance of Brownian movements (with notes on sponges and protista). Proc. Linn. Soc. Lond., Sess. I43, I930-31, pp. 82-96.

1932. Modern progress in vertebrate palaeontology. A Review. Proc. S.W. Nat. Un., Vol. 2, pp. 132-3.

1932. Senescence. Brit. med. F. 24 Sept., 7 pp.

1932. Fresh-water sponges of the Cam basin. Nat. Hist. Wicken Fen, Pt. vr, pp. 637-43.

1933. Sponges without collared cells. Nature, Lond., Vol. 132, pp. 44I-2.

1933. The energy of flagellate cells. Rep. Brit. Ass., 1933, p. 486. 
1934. The generic name Tethya. An example of the operation of the laws of nomenclature. Proc. Linn. Soc. Lond., Sess. 146, 1933-34, pp. 103-8.

1937. The perfection of sponges. Proc. Linn. Soc. Lond., Sess. 149, 1936-37, pp. I I9-46.

1941. Weighing living marine animals. Nature, Lond., Vol. I47, pp. 328-9.

\section{Obituaries}

1935. Joseph Thomas Cunningham (1859-1935). 7. Cons. int. Explor. Mer, Vol. Io, pp. 245-8.

1941. Obituary. Mr W. H. Caldwell. Nature, Lond., Vol. I48, pp. 557-8.

1943. Edgar Johnson Allen, I866-1942. F. Mar. biol. Ass. U.K., Vol. 25, pp. $671-84$.

Other works

1899. By Southern Shore. (Poems.)

I899. Merlin's Youth. (Poems.)

1919. 'Arcus.' 7. Philology, Vol. 35, pp. I I3-27. 


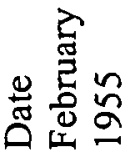

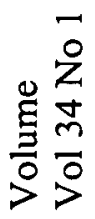

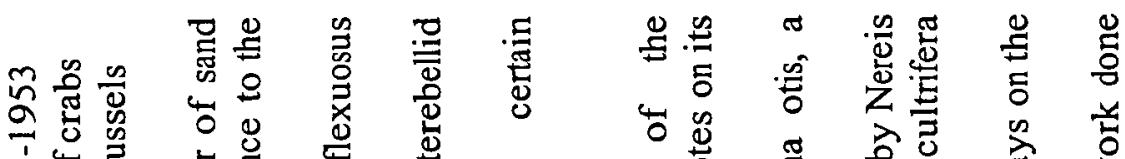

ஸ்

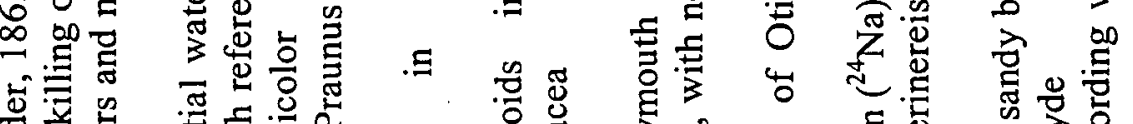

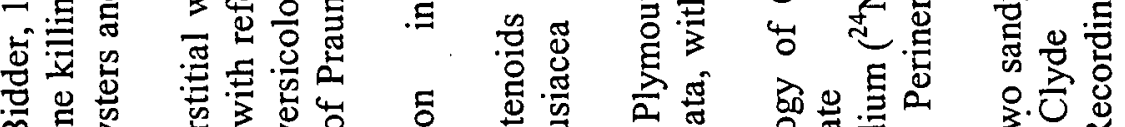

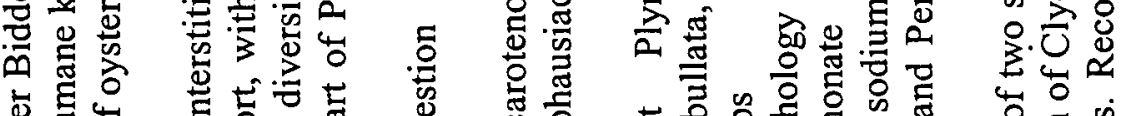

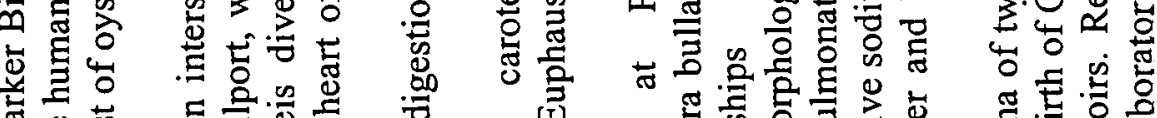

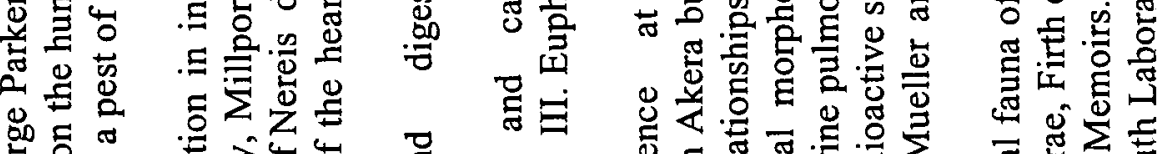

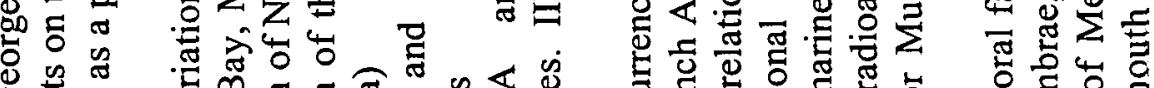

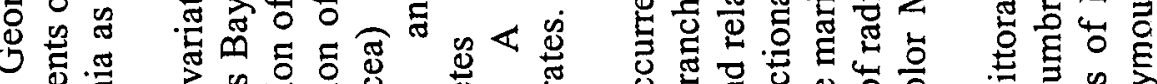

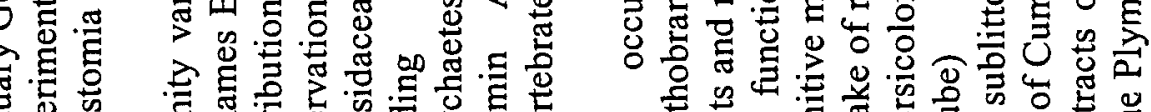

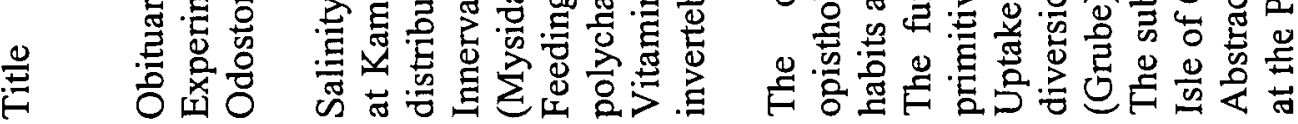
車

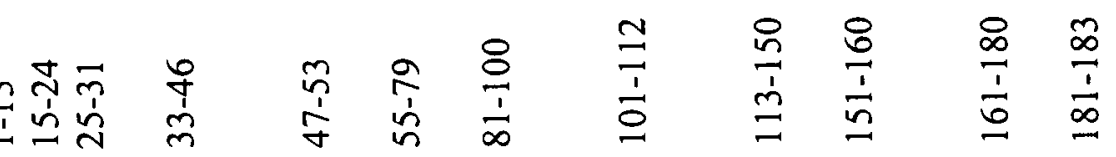

